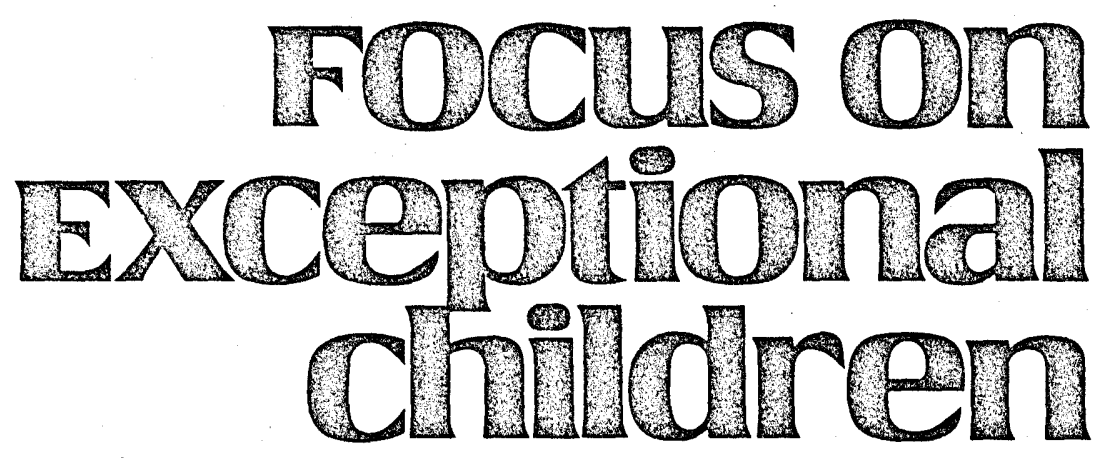

\title{
Social Skills Curricula for Mildly Handicapped Adolescents: A Review
}

\author{
Jean Bragg Schumaker, Colleen Smalter Pederson \\ J. Stephen Hazel, and Edward L. Meyen
}

A critical measure of success and adjustment for mildly handicapped adolescents and young adults is the degree to which they can interact effectively on a social basis (Alley \& Deshler, 1979; Siegel, 1974; Zigmond \& Brownlee, 1980). Consideration of social skills becomes important for educators of the mildly handicapped in light of recent research showing that mildly handicapped adolescents exhibit significant social skill deficits when compared to their nonhandicapped peers (e.g., Mathews, Whang, \& Fawcett, 1980; Schumaker, Hazel, Sherman, \& Sheldon, 1982) and that mildly handicapped young adults report dissatisfaction with their social lives (e.g., Vetter, 1983; White, Schumaker, Warner, Alley, \& Deshler, 1980).

Competence in the social realm should enhance the life adjustment of mildly handicapped individuals - whether they are learning disabled, emotionally disturbed, or mildly retarded -in a number of areas. First, social competence may allow mildly handicapped students to gain more from their educational experiences (Zigmond, 1978). Second, social skill competence would enhance the ability of the mildly handicapped to freely $\mathrm{mix}$ and enjoy activities with their nonhandicapped peers (Gresham, 1981).Third, mildly handicapped adolescents and young adults who are unfortunate enough to commit criminal acts, may find that social competence can make the difference between being allowed to remain in the community or being placed in a correctional institution (e.g., Cohn, 1963; Gross, 1967). A final area in which social skill competence impacts a youth's life outside of school is the world of work. The ability to obtain a job and successfully hold a job has been found to relate to social competence (Fulton, 1975); social skills might compensate for academic deficits and allow the mildly handicapped to successfully compete with their nonhandicapped peers in the job market.

Given the importance of social skill competence for successful adjustment in educational, social, and work settings, training appropriate social behaviors in mildly handicapped adolescents is an essential instructional goal. The realization of this instructional goal is contingent, in part, upon selection and use of curricula that effectively teach appropriate social behaviors. Unfortunately, few social skills curricula

Jean Schumaker is Coordinator of Research, Institute for Research in Learning Disabilities, and Courtesy Assistant Professor, Departments of Human Development and Special Education, University of Kansas. Colleen Pederson is Curriculum Development Specialist, Institute for Research in Learning Disabilities, University of Kansas. J. Stephen Hazel is Research Associate, Institute for Research in Learning Disabilities, and Assistant Professor (Adjunct), Department of Human Development and Family Life, University of Kansas. Edward Meyen is Acting Vice-Chancellor and Professor of Special Education, University of Kansas. 
have been designed specifically for mildly handicapped persons.

This article reviews the social skills curricula available to educators of mildly handicapped students. First we discuss a number of considerations that are important to teachers in selecting instructional resources for teaching social skills. This is followed by a review of currently available social skills curricula and their relationship to these considerations. Finally, we describe three recently completed, federally funded curriculum development projects in light of the considerations addressed.

\section{FIVE IMPORTANT CONSIDERATIONS IN SELECTING A SOCIAL SKILLS CURRICULUM FOR THE MILDLY HANDICAPPED}

\section{Does the Curriculum Promote Social Competence?}

Goldfried and D'Zurilla (1969) defined competence in the social realm as "the effectiveness or adequacy with which an individual is capable of responding to the various problematic situations which confront him" ( $p$. 161). Others have defined competence in the social arena

\section{Focus on children}

FOCUS ON EXCEPTIONAL CHILDREN (ISSN 0015-511X) (USPS 203-360) is published monthly except June, July, and August as a service to teachers, special educators, curriculum specialists, administrators, and those concerned with the special education of exceptional children. This journal is abstracted and indexed in Exceptional Child Education Resources, and is also available in microform from Xerox University Microfilms, Ann Arbor, Michigan. Subscription rates, $\$ 18.00$ per year. Copyright - 1983, Love Publishing Company. All rights reserved. Reproduction in whole or part without written permission is prohibited. Printed in the United States of America. Second class postage is paid at Denver, Colorado. POSTMASTER: Send address changes to:

\footnotetext{
Love Publishing Company

Executive and Editorial Office

1777 South Bellaire Street

Denver, Colorado 80222

Telephone (303) 757-2579
}

\section{EDITORIAL BOARD}

Edward L. Meyen

University of Kansas
Glenn A. Vergason Georgia State University as the ability to interact with others so that positive effects are produced for the individual and other involved parties in given situations (Combs \& Slaby, 1977; Foster \& Ritchey, 1979). Still others view social competence as a complex set of verbal and nonverbal responses that are emitted in response to environmental stimuli and that produce positive environmental consequences (Libet \& Lewinsohn, 1973; Rinn \& Markle, 1979).

When viewed as a complex composite of several skills, the instruction of social competence is a difficult task for the special educator. Not only is the composite of skills complex, but each of the skills in the composite also can be characterized as complicated. Further, the skills must be performed in synchronization and with a certain measure of fluency if an individual is to be accepted by other persons. In addition, learning these complicated skills and actually using the skills takes motivation. Thus, a socially competent person must have the required social skills in his/her repertoire and must be motivated to achieve social goals (e.g., making friends, persuading others, pleasing authority figures). To be effective, a social skills curriculum should enhance the motivation of students to interact successfully or should enable students to actually use social skills. Preferably, a social skills curriculum will do both.

\section{Does the Curriculum Accommodate the Learning Characteristics of the Mildly Handicapped?}

Another important consideration when choosing a social skills curriculum is whether the curriculum has been designed to accommodate the strengths and weaknesses of the mildly handicapped population. The social skills curricula reviewed in this article are discussed with regard to their appropriateness for three groups of mildly handicapped adolescents and young adults: the learning disabled (LD), the mildly mentally retarded (MR), and the emotionally disturbed (ED).

As Hallahan and Kauffman (1977) have indicated, the characteristics associated with the three target populations have considerable overlap. First, the intellectual ability, as measured by intelligence tests, of mentally retarded (Grossman, 1973), learning disabled (Warner, Alley, Schumaker, Deshler, \& Clark, 1980), and emotionally disturbed students (Hallahan \& Kauffman, 1978) is below average. In addition, the mildly retarded (Hewett, 1977), the learning disabled (Warner et al., 1980), and the emotionally disturbed (Kauffman, 1977) all show low levels of achievement.

Common learner characteristics exhibited by the three mildly handicapped groups suggest that a social skills curriculum selected for the mildly handicapped must be 
simple and easy to understand. Materials should be written at low readability levels such that a majority of the mildly handicapped population can read and understand them without difficulty. Concepts must be presented in a highly structured way with several examples presented in several modes (e.g., pictures, audiotapes). Writing requirements should be minimal.

In addition to the obvious learner characteristics of ability and achievement levels, other learning factors must be considered when selecting a social skills curriculum for the mildly handicapped. As each social situation presents itself, the individual must discriminate the significant situational cues, consider the possible skills to be used, consider the consequences that can result from use of each skill, and then choose the best skill for the situation. Yet, discrimination of significant cues is one skill in which the mildly handicapped show deficits (e.g., Zeaman \& House, 1963). In addition, mildly handicapped students are often poor problem solvers. Instead of carefully considering a problem task, they tend to be impulsive (Heal \& Johnson, 1970; Mellard \& Alley, 1981) and not consider various alternative solutions (Schumaker et al., 1982).

Another learning characteristic is the target population's response to failure. Zeaman and House (1963) have termed this "failure set." When individuals who have experienced much failure in their lives encounter failure again, they tend to resist similar learning tasks even if the tasks are easier than the tasks on which they have experienced failure. Robinson and Robinson (1976) suggested that learning tasks should be presented in an easy-to-hard sequence for the failure-prone population. This ensures positive reinforcement of early approximations and avoids the resistance that may result from experiencing failure.

Robinson and Robinson (1976) described retarded individuals as passive learners who fail to use aids such as rehearsal or elaboration in learning. Butterfield and Belmont's (1977) research indicated that few retarded individuals spontaneously use a strategy when tackling a complex memory task. Research utilizing a serial recall task, by Warner, Schumaker, Alley, and Deshler (1983), indicates that less than one-half of LD adolescents employed efficient learning strategies. Including strategies or organizational schemes in social skills curricula may facilitate acquisition of the material.

Recent attempts to teach social skills in mildly handicapped students have shown that although these individuals may be able to learn the skills, they have difficulty in generalizing learned skills to real-life situations (Gorney-Krupshaw, Atwater, Powell, \& Morris, 1981; Schumaker \& Ellis, 1982). These findings indicate that a social skills curriculum, to be appropriate for the mildly handicapped, should specifically program generalization of newly learned skills across settings and conditions.

A final area of concern when selecting a social skills curriculum for the mildly handicapped is their motivation to learn and to complete learning tasks. For example, recent research shows that LD adolescents have difficulty setting goals for themselves and following through on those goals (Tollefson, Tracy, Johnsen, Borgers, Buenning, Farmer, \& Barke, 1980). They tend to set very low or very high goals instead of realistic goals; and they often fail to accomplish their goals. Other research is promising, however, showing that LD adolescents can learn to set goals, record and evaluate their own progress, and reward themselves for accomplishments (Seabaugh \& Schumaker, 1981). These skills should be incorporated in a social skills curriculum if the students using it are to generalize their newly learned skills outside of the learning setting. They will have to motivate themselves to use the skills, evaluate their own progress, and reward themselves. Teachers will not be available to fulfill these functions outside of the learning setting.

In summary, several factors must be considered in selecting a social skills curriculum that effectively addresses the learning characteristics of mildly handicapped adolescents or young adults. The curriculum should:

-capitalize on the common learning characteristics of the mildly handicapped groups and yet provide materials or suggestions for adapting the curriculum to suit the distinct needs of each group.

- be simple and easy to understand, with low readability levels and a minimum of required writing.

- provide for the discrimination of significant social cues and the acquisition of problem-solving skills.

- be programmed for a minimum of student failure and provide reinforcement for each successful step toward mastery.

- provide the student with strategies for acquiring the skills.

-provide procedures for assuring, as well as measuring, the generalization of learned skills to naturally occurring situations.

- provide motivation for the learners to set and accomplish social goals once a social skill has been acquired.

\section{Does the Curriculum Target the Social Skill Deficits of the Mildly Handicapped Population?}

Recent research has shown that LD adolescents perform significantly poorer than their nonhandicapped peers in the following skills: accepting negative feedback; 
conversation; giving negative feedback; giving positive feedback; negotiation; problem solving; and resisting peer pressure (Schumaker et al., 1982); participating in a job interview, accepting criticism from an employer; providing constructive criticism to a co-worker; and explaining a problem to a co-worker (Mathews, Whang, \& Fawcett, 1980).

Other research with LD adolescents has shown that they rarely participate in organized activities in and out of school (Deshler, Schumaker, Warner, Alley, \& Clark, 1980). This pattern of low participation appears to continue after high school as well. LD young adults belong to significantly fewer social organizations than their peers, and they engage in recreational activities significantly less often (White et al., 1980). When interviewed, $L D$ young adults indicated that they were bored with leisure time, did not know what to do with their free time, and that dating was not attractive to them because they did not know "what to say" to people of the opposite sex (Vetter, 1983). These social problems indicate that $\mathrm{LD}$ adolescents and young adults need to learn skills in areas such as initiating activities, joining group activities, conversation, and making friends.

Similar difficulties seem to be exhibited by MR adolescents and young adults. Kelly and Drabman (1977) found that retarded adolescents engage in inappropriate social behaviors that lead peers to avoid their company. Kelly, Wildman, Urey, and Thurman (1979) found very low levels of performance with respect to the rudimentary social skills of asking questions to elicit information about a peer, making self-disclosing statements, and directing specific compliments to a partner. In terms of post-school adjustment, EMR young adults do marry and hold jobs, but the jobs they hold tend to be low status and low paying jobs (MacMillan, 1977). Further, EMR young adults report lower levels of satisfaction with their marital situations than their peers (Gozali, 1972).

With regard to the behaviorally disordered adolescent, Hazel, Schumaker, Sherman, \& Sheldon-Wildgen (1981) asked delinquent youths and their parents to identify situations that were problematic for the youths. Example problem situations included receiving criticism from a teacher, arguing with siblings, getting into trouble with friends, inappropriately expressing one's point of view, and not following instructions from parents. The majority of situations mentioned were directly related to skills such as negotiation, personal problem solving, resisting peer pressure, following instructions, accepting criticism, giving criticism, conversation, and giving positive feedback.

Although the research on social skill deficits of the mildly handicapped has not been extensive, training in the following skills appears to be needed: giving and accepting negative feedback; giving positive feedback; negotiation; problem-solving; resisting peer pressure; participating in a job interview; explaining a problem; initiating activities; joining activities; making friends; asking questions; making self-disclosing statements; following instructions; and conversation. These skills should be applicable in school, job, and community settings.

\section{Does the Curriculum Provide Training in Situations as Well as Skills?}

Since one of the requirements for appropriate use of social skills is the ability to discriminate situations in which the skills are used, two types of content must be covered in a social skills curriculum: the skills and the situations in which the skills can be used. In a social skills training program, one can begin training with either type of content. When training begins with the situations, the approach can be called the "problem-specific approach." When training begins with the skills, the approach can be called the "general skills approach."

Through use of the problem-specific approach, a problem social situation encountered by the learner is identified and an effective social response to that situation is taught. The problem-specific approach yields solutions to specific problems (e.g., how to accept criticism for a poor test grade from the math teacher) but does not necessarily produce behaviors that will be generalized to other similar situations. Another disadvantage of this approach is that an individual can potentially encounter an infinite number of problem situations. To teach someone responses to every possible situation would be impossible.

In the general skills approach, training begins with the general skills that are required in classes of social situations. By teaching a general skill sequence (e.g., how to accept criticism), not only is the number of trained social skills greatly reduced, but generalization to novel problem situations is also enhanced because of the emphasis on generality of the skills. Both the general skills and their relationship to problem situations can be taught through the general skills approach. This approach has the advantage of teaching generalizable skills while the learner is made aware of the types of situations in which the skills will be effective.

When selecting a social skills curriculum for the mildly handicapped, then, the educator should consider the following factors with regard to content. A curriculum:

- must address not only the necessary information on the social skills themselves but also teach how to discriminate which situations require which skills. 
-should include instruction in general skill sequences tied to a variety of related problems, to promote generalization.

\section{Does the Curriculum Incorporate Instructional Method- ologies Found to be Effective with the Mildly Handicapped?}

In the last few years several social skills training programs for select subgroups of the mildly handicapped have been reported. In studies with mentally retarded (e.g., Arnold, Sturgis, \& Forehand, 1977; Kelly, Furman, Phillips, Hathorn, \& Wilson, 1979; Kelly et al., 1979; and Rychtarik \& Bornstein, 1979), learning disabled (e.g., Gorney-Krupshaw et al., 1981; Whang, Fawcett, \& Mathews, 1981; and Hazel, Schumaker, Sherman, \& Sheldon, 1982), and emotionally disturbed/behaviorally disordered (e.g., Clark, Caldwell, \& Christian, 1979; and Hazel et al., 1981), a basically similar teaching methodology was used regardless of whether the training targeted individuals or groups. First, the clients were made aware of the skill. This "awareness" phase of the training usually involved some combination of the following techniques: describing the new skill, giving rationales for using the skill, describing the general characteristics of situations, providing example situations in which the skill can be used, specifying the behavioral components of the skill, and presenting a model of the skill to the client(s). This awareness phase of training was presented either through lecture-discussion or through written materials.

The next crucial phase of training in most studies can be labeled "practice." Here, two types of practice have been utilized: verbal rehearsal (memorization) of the steps, and behavioral rehearsal of the skill in simulated situations. Verbal rehearsal of the steps is important in that the students need to be able to instruct themselves on what to do next as they perform a skill (Alley \& Deshler, 1979). Only by knowing the steps of a skill "cold" can they do this self-instruction. Most successful social skills training studies have included a behavioral rehearsal component in which the learners practiced the skill(s) in role-play situations. Some of the trainers have required the learners to practice until a mastery criterion is reached. This practice training step, complete with required mastery, would seem to be especially important for handicapped clients. Hazel et al. (1981) reported that youths who did not practice the social skills to criterion were not able to use the skills in novel role-playing situations. If youths cannot use the skills in role-playing situations where they are being cued to use the skills, they would not likely use them elsewhere.

Practice activities are usually combined with feedback from another individual. This feedback usually includes positive comments regarding the skill steps an individual has performed well and corrective comments and suggestions regarding the skill steps that individual has omitted or performed poorly.

The third phase of training, emphasized by only a few studies, is "application." Here, the students are encouraged to use the skills outside the training situation in naturally occurring situations. "Application" or generalization activities generally require students to use the learned skills, evaluate their performance, and reward themselves. These activities often include games, home assignments, goal sheets, and contingency contracts.

Closely allied with a successful teaching methodology that incorporates awareness, practice, and application activities must be a reliable and valid assessment device that can be used to measure learners' progress. Unless an assessment device is utilized, there is no way of determining a youth's social skills at entry into a program, whether a youth has learned to perform a skill, and whether the performance is at or above the criterion level. In light of the Hazel et al. (1981) finding that youths must practice to criterion levels if they are to be expected to use the skill in novel situations, the importance of an assessment device to measure youths' performances becomes clear. Assessment devices that have been used to measure social skill performance by learners include questionnaires, skill checklists, and observation codes.

In summary, when selecting a social skills curriculum for mildly handicapped adolescents, the teaching methodology should be reviewed. Ideally, it should include methodologies related to making the student aware of the skill, giving the student opportunities to practice the skill, and arranging for opportunities for the student to use the skill in settings outside of the training setting. It should also include a method for measuring student performance of social skills; that is, the curriculum:

- should make the student aware not only of the specific behaviors involved in the skill but also the rationales for using the skill once it is learned and the situations in which use of the skill is appropriate; should include examples and models of appropriate use of the skills.

- must provide opportunity for the student to practice the skill to criterion both through verbal rehearsal and behavioral rehearsal of the skill (this "practice" phase usually occurs within the training setting).

- should contain components to assure that the student recognizes the need for a particular skill in a naturally occurring situation and uses the skill appropriately in that situation; the "application" or generalization activities should promote use of the skill outside the 
training setting.

- should contain a reliable and valid assessment device

for measuring learners' skills upon entry into training, learners' progress, and learners' mastery attainment.

\section{A SELECTED REVIEW OF CURRENTLY AVAILABLE SOCIAL SKILLS CURRICULA}

For the purpose of this review, currently available social skills curricula were analyzed. Curricula that focused on interactional behaviors between individuals, that were designed for adolescents, and that addressed at least some of the considerations specified above were selected for inclusion.

Table 1 (pp. 8-9) presents a summary of how eight social skills curricula developed for the adolescent population in general address the important considerations for selecting social skills curricula. Along the top of the table are listed, in alphabetical order, the names of the social skills curricula, their publishers, and dates of publication. The complete name and address of the publisher of each curriculum is listed at the end of this article. On the left side of the table, seven factors are listed: the population for whom the curriculum is targeted, a physical description of the curriculum, and the five considerations including how the curriculum addresses social competence through ability and motivation factors, how the learning characteristics of the mildly handicapped are addressed, the social skills or topics covered by the curriculum, the content approach utilized (problemspecific/general skills), and the teaching methodology employed. As can be seen in the table, the curricula were designed for a variety of target populations including secondary students, prevocational learners, adolescents with behavior problems, and anyone over age 8 .

With regard to format, four of the eight programs include some sort of audio or visual media that could be helpful for teachers of students who have major problems with reading and writing. A number of the curricula (ASSET, Skillstreaming, Transition) consist primarily of materials for teachers' use and presentation. Thus, the activities in these programs could be adapted by a creative teacher for learners with special needs.

Most of the curricula have as their primary focus either ability or motivation. If both ability and motivation are listed for a curriculum (in the third horizontal row of the table), the one listed first is the primary focus of the curriculum. Four of the curricula focus on ability, but three of the curricula (ASSET, Developing Social Skills, and Skillstreaming) focus on teaching specific social skills complete with behaviorally defined components (skill steps). Several of the curricula (Consequences, Getting
Along at Work, Roll-A-Role) can be used as tools to increase individuals' motivation to use the social skills they already have integrated within their behavioral repertoires.

Each of the curricula addresses some of the learner characteristics discussed previously. Information pertinent to these characteristics is listed in the fourth horizontal row of the table. If the reading level was stated in the curriculum or in the publisher's catalog, it is given here. If no reading level was provided, a readability score was derived using the Dale-Chall formula (Dale \& Chall, 1948). Each score is based on a review of the print materials (situation cards, skill sheets, duplication masters) that are integral to a curriculum.

For some of the programs, even though a readability level is specified, the student need not do reading. Teachers could orally present the information in some of these materials (the skill sheets) or adapt the reading level to suit their students' abilities. Writing requirements vary. Some programs require no writing; others require true/false symbols, one-word answers, or one-sentence answers. One program (Person to Person) requires the student to write full paragraphs and short themes.

The skills/topics targeted by the curricula, as a group, cover a broad area. Only selected subjects are given in the table when the complete list of skills/topics is too extensive to include in its entirety. When the skills/topics are specifically named in the curriculum, the first letter of each skill is capitalized in the table. When skills/topics were derived by analyzing the curriculum content, the first letters are not capitalized. Concerning the content approach utilized in each of the curricula, four of the curricula employ the general skills approach, and the remaining curricula utilize the problem-specific approach.

The teaching methodologies employed vary. The last horizontal column in the table is a synopsis of how a curriculum utilizes the awareness, practice, and application methodologies. It also lists additional techniques that have been shown to be useful in teaching social skills. As can be seen, awareness activities are usually presented through audiovisual media, lecture-discussion activities, or reading and writing assignments. Practice activities usually consist of role playing or a similar structured rehearsal of a skill. Application activities, when present, usually involve an assignment, outside of the learning setting in which the learners must use the socia! skills they have learned in class.

Four of the curricula incorporate at least some of the teaching techniques found to be successful in teaching social skills-demonstrations (models) of the appropriate performance of social skills, reinforcement for correct performance, repetition of information/practice, assess- 
ment of skill usage, and mastery of the skills-within their teaching methodologies; however, rarely are all of the techniques combined in one curriculum.

Table 2 (p. 10) shows similar information for four social skills programs designed specifically for handicapped adolescents. Three of the programs were developed for handicapped students as a group, and one focuses primarily on the developmentally disabled population. One of the programs includes audiovisual media; one of the programs includes student workbooks; and a third program includes both. A fourth program (the IEP-3 Kit) was designed to help teachers develop IEP goals and objectives; it incorporates suggested activities for fulfilling each objective.

Of the four programs, two focus primarily on motivating learners to use social skills. The other two programs emphasize social skill ability. All of these programs take into account in some way the academic skill deficits of handicapped learners. The programs either require no reading or materials are written at low readability levels. The writing requirements of the programs vary from no writing to short themes (e.g., a personal or business letter).

With regard to the skills/topics covered in the programs, these programs are directed at a less broad area than the programs reviewed for the adolescent population in general. Two of the programs (The Good Life, IEP-3) focus on skills such as personal hygiene in addition to some rudimentary social skills. The program (The Promise, etc.) that addresses topics such as dealing with conflict and authority concentrates mainly on the motivational aspects of these skills versus the performance of them. The fourth program (Social Consequences) focuses on the consequences contingent on behavior in different kinds of settings.

The content approaches employed in the four programs seem to correspond to a focus on ability or on motiviation. Those that focus on ability use the general skills approach; those that focus on motivation use the problem-specific approach.

Considering the teaching methodologies utilized in the four programs, two of the programs incorporate awareness, practice, and application activities; the other two include only awareness and practice activities. Two of the programs contain additional successful techniques for training social skill usage, including mastery criterion, models, reinforcement, and repetition.

\section{RECENT SOCIAL SKILLS CURRICULUM DEVELOPMENT PROJECTS}

According to the above review, although various materials have been developed for teaching social skills, few materials currently on the market incorporate content and teaching methodologies specifically appropriate for the mildly handicapped adolescent and young adult. Also, none of these programs addresses the wide range of interpersonal skill deficits present in the population while ensuring mastery and generalization of the skills to the natural environment. This is not surprising in light of Vale's (1978) surwey of over 30,000 educators in the United States to determine the curricular needs of special education teachers. In the survey, teachers of the mildly mentally handicapped, emotionally disturbed, and learning disabled over the age of 12 most frequently mentioned social skills materials as their highest curricular need. These same teachers also stated that, regardless of the subject matter, they needed more curriculum materials designed specifically for special education learners.

In 1981, in response to the Vale study, the U.S. Department of Education granted three separate contracts to develop social skill curriculum materials for mildly handicapped adolescents and young adults. Each project adopted a unique perspective toward specification and development of a social skills curriculum for mildly handicapped persons. Each project will be briefly reviewed here, including a description of the curriculum and of the ways the curriculum addresses the five considerations discussed previously. These projects each included an extensive field-test evaluation of its material. The results of these evaluations were promising but are not included in this discussion.

\section{The Marathon Program}

The Marathon program, developed by ABT Associates, was designed to teach social behaviors to secondary school students who have mild cognitive impairments such that they can succeed on the job and in the community. Marathon's primary audience is the secondary learning disabled and educable mentally retarded. The program also may be helpful to slow learners and students who are learning English as a second language.

This program includes several different elements. Two student workbooks emphasize the relationship between and among success, effort, and social skills, and two lesson-by-lesson teacher's guides suggest strategies and activities for motivating students and teaching social skills.

A sound filmstrip, "The Matching Game," uses a gameshow format to show students how to succeed in specific situations. Another sound filmstrip, "You Run Your Life," also uses a gameshow format to emphasize ways we can control our behavior to gain success. The filmstrips can be used to introduce or review the student 
Curricula Designed for

\begin{tabular}{|c|c|c|c|c|}
\hline & $\begin{array}{l}\text { ASSET } \\
\text { Research Press } \\
1981\end{array}$ & $\begin{array}{l}\text { CONSEQUENCES/ } \\
\text { POINTS OF VIEW/ } \\
\text { SENSITIVITY } \\
\text { Developmental Learning } \\
\text { Materials } \\
1975\end{array}$ & $\begin{array}{l}\text { DEVELOPING SOCIAL SKILLS: } \\
\text { LEARNING CONVERSATIONAL } \\
\text { TECHNIQUES } \\
\text { Human Relations Media } \\
1980\end{array}$ & $\begin{array}{l}\text { GETTING ALON } \\
\text { Media Materials } \\
1979\end{array}$ \\
\hline Target Population & $\begin{array}{l}\text { Adolescents with behavior } \\
\text { problems }\end{array}$ & Secondary learners & Not given & Prevocational lea \\
\hline $\begin{array}{l}\text { Physical } \\
\text { Description }\end{array}$ & $\begin{array}{l}\text { Ejght videotapes/films, Leader's } \\
\text { Guide (162 pgs.), program materials } \\
\text { (skill sheets, skill checklists). }\end{array}$ & $\begin{array}{l}\text { Three separate curricula each with } \\
\text { situation cards }(N=71,63,46) \text {, Tea- } \\
\text { cher's Manual }(15,23,34 \text { pgs. }) \text {, and } \\
\text { plastic storage box. }\end{array}$ & $\begin{array}{l}\text { Four audiotapes with four filmstrips, } \\
\text { Teacher's Guide ( } 74 \text { pgs. including } \\
\text { script of filmstrips). }\end{array}$ & $\begin{array}{l}\text { One filmstrip wi } \\
\text { student booklets, } \\
\text { (10 pgs.). Part of } \\
\text { series. }\end{array}$ \\
\hline $\begin{array}{l}\text { Ability and/or } \\
\text { Motivational } \\
\text { Components }\end{array}$ & $\begin{array}{l}\text { Ability by teaching specific skill se- } \\
\text { quences, which are practiced to } \\
\text { mastery with feedback provided. } \\
\text { Motivation by providing students } \\
\text { with rationales and reinforcement } \\
\text { for appropriate behavior. }\end{array}$ & $\begin{array}{l}\text { Motivation by promoting consid- } \\
\text { eration by the students of how } \\
\text { others feel and the consequences } \\
\text { of their own actions. }\end{array}$ & $\begin{array}{l}\text { Ability by specifying the behavioral } \\
\text { components of social skills. Moti- } \\
\text { vation by stressing the importance } \\
\text { of the skills in fulfilling personal } \\
\text { needs. }\end{array}$ & $\begin{array}{l}\text { Motivation by re } \\
\text { social skills on } \\
\text { retention and pro }\end{array}$ \\
\hline $\begin{array}{l}\text { Learning } \\
\text { Characteristics } \\
\text { Addressed }\end{array}$ & $\begin{array}{l}\text { Video format with group discussion } \\
\text { keeps reading minimal. (Reading } \\
\text { level of skill sheets=7-8th grade, } \\
\text { Dale-Chall.) No writing is required. } \\
\text { Problem solving is taught as a skill, } \\
\text { and discriminating cues is covered } \\
\text { by discussing general character- } \\
\text { istics of situations in which the skill } \\
\text { should be used. Generalization } \\
\text { procedures are provided. }\end{array}$ & $\begin{array}{l}\text { Cards are used by the instructor as } \\
\text { a stimulus for other activities (i.e., } \\
\text { discussion, role play, mime). Em- } \\
\text { phasis is on verbal rather than } \\
\text { written activities. }\end{array}$ & $\begin{array}{l}\text { Although concept level is high, no } \\
\text { reading or writing is required. Study } \\
\text { questions may be administered or- } \\
\text { ally. Behavioral contracting is re- } \\
\text { commended to stimulate gener- } \\
\text { alization of techniques. Problem } \\
\text { solving is taught using a process } \\
\text { called DESC scripting. }\end{array}$ & $\begin{array}{l}\text { Maximum reading } \\
\text { sentence passag } \\
=5-6 \text { th grade, Dale } \\
\text { writing is a sente }\end{array}$ \\
\hline $\begin{array}{l}\text { Skills or Topics } \\
\text { Covered }\end{array}$ & $\begin{array}{l}\text { Giving Positive Feedback } \\
\text { Giving Negative Feedback } \\
\text { Accepting Negative Feedback } \\
\text { Resisting Peer Pressure } \\
\text { Problem Solving } \\
\text { Negotiation } \\
\text { Following Instructions } \\
\text { Conversation }\end{array}$ & $\begin{array}{l}\text { Consequences } \\
\text { Cause and effects } \\
\text { safety } \\
\text { emotions } \\
\text { morality } \\
\text { cooperation } \\
\text { environment } \\
\text { Points of View } \\
\text { Needs and values } \\
\text { age } \\
\text { race } \\
\text { sex } \\
\text { culture } \\
\text { politics } \\
\text { personal behavior } \\
\text { Sensitivity } \\
\text { Sympathy and understanding }\end{array}$ & $\begin{array}{l}\text { eye contact } \\
\text { body posture } \\
\text { facial expressions } \\
\text { personal space } \\
\text { voice tone } \\
\text { questions } \\
\text { self-disclosure } \\
\text { conversation } \\
\text { self-esteem } \\
\text { self-praise } \\
\text { accepting criticism } \\
\text { public speaking } \\
\text { dealing with conflict } \\
\text { relaxation } \\
\text { assertion }\end{array}$ & $\begin{array}{l}\text { Topics: } \\
\text { being on time } \\
\text { avoiding absente } \\
\text { following directic } \\
\text { asking questions } \\
\text { making friends } \\
\text { handling conflict } \\
\text { responding to te }\end{array}$ \\
\hline $\begin{array}{l}\text { Approach (Skills or } \\
\text { Situations) }\end{array}$ & $\begin{array}{l}\text { General skills approach: Specific } \\
\text { behavioral steps are given for each } \\
\text { skill including verbal and nonverbal } \\
\text { behaviors. Each skill is practiced to } \\
\text { criterion in various situations. }\end{array}$ & $\begin{array}{l}\text { Problem-specific approach: The } \\
\text { cards depict situations to which } \\
\text { the class discusses causes, effects, } \\
\text { and alternatives. }\end{array}$ & $\begin{array}{l}\text { General skills approach: Focuses } \\
\text { on techniques associated with suc- } \\
\text { cessful skill use. Emphasizes pro- } \\
\text { cess of social interaction as op- } \\
\text { posed to.end results. }\end{array}$ & $\begin{array}{l}\text { Problem-specific } \\
\text { problem situatio } \\
\text { discussed, and a } \\
\text { iors are suggeste }\end{array}$ \\
\hline $\begin{array}{l}\text { Teaching } \\
\text { Methodology }\end{array}$ & $\begin{array}{l}\text { Awareness through group discus- } \\
\text { sion and viewing films. } \\
\text { Practice through structured role } \\
\text { plays. Example situations are pro- } \\
\text { vided if learners have difficulty } \\
\text { generating their own. } \\
\text { Application through the use of the } \\
\text { "Gotcha Game" and Home Notes. } \\
\text { Models } \\
\text { Reinforcement } \\
\text { Repetition } \\
\text { Mastery Criteria for role playing } \\
\text { performances } \\
\text { Assessment of live performance } \\
\text { using a skill checklist }\end{array}$ & $\begin{array}{l}\text { Awareness through free thought } \\
\text { and discussion stimulated by the } \\
\text { situation cards. } \\
\text { Practice through role playing is } \\
\text { suggested in the Teacher's Manuals, } \\
\text { although specific guidelines for } \\
\text { role playing are not given. }\end{array}$ & $\begin{array}{l}\text { Awareness through viewing film- } \\
\text { strips and class discussion. Study } \\
\text { questions are also provided. } \\
\text { Application through behavioral } \\
\text { contracting. } \\
\text { Models } \\
\text { Reinforcement } \\
\text { Repetition } \\
\text { Assessment of one's probable per- } \\
\text { formance in given situations using } \\
\text { questionnaire ratings. }\end{array}$ & $\begin{array}{l}\text { Awareness by } \\
\text { participating in } \\
\text { and responding il } \\
\text { Practice by role } \\
\text { mended in the fo } \\
\text { Five specific situ }\end{array}$ \\
\hline
\end{tabular}




\section{al Adolescent Population}

\begin{tabular}{|c|c|c|c|}
\hline $\begin{array}{l}\text { PERSON TO PERSON } \\
\text { Bennett Publishing } \\
1981\end{array}$ & $\begin{array}{l}\text { ROLL-A-ROLE } \\
\text { The Ungame Company } \\
1976\end{array}$ & $\begin{array}{l}\text { SKILLSTREAMING THE } \\
\text { ADOLESCENT } \\
\text { Research Press } \\
1980\end{array}$ & $\begin{array}{l}\text { TRANSITION I-V } \\
\text { American Guidance Service } \\
1979\end{array}$ \\
\hline Not given & "Ages 8 to $108 "$ & $\begin{array}{l}\text { Aggressive, withdrawn, and imma- } \\
\text { ture adolescents }\end{array}$ & $\begin{array}{l}\text { Grades } 6-9 \text { (adaptations are } \\
\text { suggested in the Teacher's Manual } \\
\text { for handicapped students) }\end{array}$ \\
\hline $\begin{array}{l}\text { Student textbook ( } 392 \text { pgs.), student } \\
\text { workbook ( } 168 \text { pgs.). Teacher's } \\
\text { Guide ( } 161 \text { pgs.), and plastic stor- } \\
\text { age box. }\end{array}$ & $\begin{array}{l}\text { A dice and board game. Players } \\
\text { role play different people (not } \\
\text { themselves) in various situations } \\
\text { and settings. }\end{array}$ & $\begin{array}{l}\text { Papercover book ( } 232 \text { pgs.), three } \\
\text { audiocassettes (optional) for train- } \\
\text { ing the instructor only. }\end{array}$ & $\begin{array}{l}\text { A five-unit program. Each unit con- } \\
\text { tains a Teacher's Manual (e.g., } 87 \\
\text {-pgs.), one audiocassette, duplicating } \\
\text { masters, script booklets, and props. }\end{array}$ \\
\hline $\begin{array}{l}\text { Ability by providing general in- } \\
\text { formation about social topics. Moti- } \\
\text { vation by giving tearners rationales } \\
\text { for improving their relationships } \\
\text { with others. }\end{array}$ & $\begin{array}{l}\text { Motivation by possibly influencing } \\
\text { learners to act differently the next } \\
\text { time they encounter situations simi- } \\
\text { lar to those they have role played. }\end{array}$ & $\begin{array}{l}\text { Ability by teaching specific skill } \\
\text { sequences that are practiced and } \\
\text { by providing feedback on each } \\
\text { performance. Motivation by provi- } \\
\text { ding students with rationales and } \\
\text { reinforcement for appropriate beha- } \\
\text { vior. }\end{array}$ & $\begin{array}{l}\text { Ability by having learners role play } \\
\text { themselves and others in situations. } \\
\text { Motivation by providing students with } \\
\text { rationales for changing their behavior. }\end{array}$ \\
\hline $\begin{array}{l}\text { Materials, written in an entertaining } \\
\text { style, require extensive reading and } \\
\text { writing. (Reading level=7-8th grade, } \\
\text { Dale-Chall.) Required writing re- } \\
\text { sponses range from one word to } \\
\text { short themes. The written activities } \\
\text { do have right and wrong answers, } \\
\text { but no mastery criteria are given. }\end{array}$ & $\begin{array}{l}\text { The game is simple, easy to under- } \\
\text { stand, requires no writing and only } \\
\text { a minimum of reading. (Reading } \\
\text { level of situation cards=5-6th grade, } \\
\text { Dale-Chall.) There are no wrong } \\
\text { answers. }\end{array}$ & $\begin{array}{l}\text { The book and optional audio- } \\
\text { cassettes are to train the instructor } \\
\text { in use of Structured Learning prin- } \\
\text { ciples. Within the program, students } \\
\text { must read only the skill lists. (Read- } \\
\text { ing level of skill lists }=4 \text { th grade and } \\
\text { below.) Problem solving is ad- } \\
\text { dressed as a part of Planning } \\
\text { Skills. Generalization procedures } \\
\text { are provided. }\end{array}$ & $\begin{array}{l}\text { Required reading and writing is mini- } \\
\text { mal. (Reading level=5-6th grade, } \\
\text { Dale-Chall.) There are no right or } \\
\text { wrong answers. A gavel is used as a } \\
\text { cue to the students, especially stu- } \\
\text { dents with impulse control problems } \\
\text { and hearing and visual Impairments. } \\
\text { The curriculum in general promotes } \\
\text { a feeling of cooperation rather than } \\
\text { competition in the class. }\end{array}$ \\
\hline $\begin{array}{l}\text { Chapters cover: } \\
\text { relationships } \\
\text { decision making } \\
\text { communication } \\
\text { family life } \\
\text { lifestyles }\end{array}$ & $\begin{array}{l}\text { Selected subjects: } \\
\text { death } \\
\text { abortion } \\
\text { patriotism } \\
\text { health } \\
\text { honesty } \\
\text { morality } \\
\text { ecology } \\
\text { friendship } \\
\text { Note: Some of the situation sub- } \\
\text { jects may be considered inappro- } \\
\text { priate for school-aged learners. }\end{array}$ & $\begin{array}{l}\text { Selected skills out of a total of } 50 \\
\text { skills: } \\
\text { Maintaining a Conversation } \\
\text { Saying Thank You } \\
\text { Asking for Help } \\
\text { Apologizing } \\
\text { Convincing Others } \\
\text { Expressing Affection } \\
\text { Sportsmanship } \\
\text { Listening } \\
\text { Responding to Teasing } \\
\text { Making a Complaint } \\
\text { Giving Instructions } \\
\text { Setting a Goal } \\
\text { Using Self-Control } \\
\text { Negotiating }\end{array}$ & $\begin{array}{l}\text { Selected subjects: } \\
\text { cooperation } \\
\text { participating in a group } \\
\text { conversation } \\
\text { active listening } \\
\text { resolving conflict } \\
\text { nonverbal communication } \\
\text { interviewing } \\
\text { goal setting } \\
\text { identifying values }\end{array}$ \\
\hline $\begin{array}{l}\text { Problem-specitic approach: The } \\
\text { teacher acts as leader and dis- } \\
\text { cussion facilitator. Materials address } \\
\text { problems of adolescents in transi- } \\
\text { tion to adulthood and ways these } \\
\text { problems can be addressed. }\end{array}$ & $\begin{array}{l}\text { Problem-specific approach: Empha- } \\
\text { sizes situations. There are } 55 \text { situa- } \\
\text { tion cards provided to be practiced } \\
\text { in } 11 \text { settings with } 12 \text { different } \\
\text { roles. }\end{array}$ & $\begin{array}{l}\text { General skills approach: Behavioral } \\
\text { steps are provided for each general } \\
\text { skill. Skills are to be practiced in a } \\
\text { variety of situations that are new to } \\
\text { the students. }\end{array}$ & $\begin{array}{l}\text { General skills approach: Empha- } \\
\text { sizes skills with a variety of situa- } \\
\text { tions used to illustrate each skill. }\end{array}$ \\
\hline $\begin{array}{l}\text { Awareness by reading, participating } \\
\text { in class discussions, and completing } \\
\text { the workbook activities. } \\
\text { Practice by role playing is sugges- } \\
\text { ted in the Teacher's Guide for a few } \\
\text { activities. Specific situations are } \\
\text { not given but are left for the } \\
\text { students to generate. }\end{array}$ & $\begin{array}{l}\text { Practice by role playing. The lo- } \\
\text { cation, topic of conversation, and } \\
\text { characters are given. Dialogue must } \\
\text { be generated by the players. }\end{array}$ & $\begin{array}{l}\text { Awareness by participating in class } \\
\text { discussion and observing models } \\
\text { of correct skill performance. } \\
\text { Practice by role playing skills in the } \\
\text { group and receiving feedback from } \\
\text { observers. Role plays are struc- } \\
\text { tured, but students must generate } \\
\text { the situations and dialogue. } \\
\text { Application by "overtraining" skill } \\
\text { steps, assigning homework, and } \\
\text { providing a system of self-rein- } \\
\text { forcement. } \\
\text { Models } \\
\text { Reinforcement } \\
\text { Repetition } \\
\text { Assessment of entry skills using } \\
\text { questionnaire ratings. }\end{array}$ & $\begin{array}{l}\text { Awareness by participating in class } \\
\text { discussion and group activities. } \\
\text { Practice by role playing which is } \\
\text { integral in many activities. Also, other } \\
\text { forms of practice are used. For ex- } \\
\text { ample, a small group practices co- } \\
\text { operative behaviors by determining } \\
\text { the average height of the group. } \\
\text { Guidelines and situations for role } \\
\text { playing are available in the Teacher's } \\
\text { Manual. } \\
\text { Reinforcement } \\
\text { Repetition }\end{array}$ \\
\hline
\end{tabular}


TABLE 2

Curricula Designed for Adolescent Handicapped Learners

\begin{tabular}{|c|c|c|c|c|}
\hline & $\begin{array}{l}\text { THE GOOD LIFE } \\
\text { Hubbard } \\
1981\end{array}$ & $\begin{array}{l}\text { IEP-3 KIT: PERSONAL } \\
\text { SOCIAL, OCCUPATIONAL } \\
\text { SKILLS } \\
\text { Ebsco Curriculum Materials } \\
1978\end{array}$ & $\begin{array}{l}\text { THE PROMISE/THE BIG } \\
\text { HASSLE/THE PUT-DOWN } \\
\text { PRO/THE CHOICE } \\
\text { Janus Book Publishers } \\
1980\end{array}$ & $\begin{array}{l}\text { SOCIAL CONSEQUENCES SERIES } \\
\text { Interpretive Education } \\
1979\end{array}$ \\
\hline Target Population & $\begin{array}{l}\text { Developmentally disabled adults and } \\
\text { adolescents with IQs from } 20 \text { to } 80\end{array}$ & $\begin{array}{l}\text { Secondary or adult EMR and LD tea- } \\
\text { chers }\end{array}$ & Secondary special education students & $\begin{array}{l}\text { High school and young adult special } \\
\text { learners }\end{array}$ \\
\hline $\begin{array}{l}\text { Physical } \\
\text { Description }\end{array}$ & $\begin{array}{l}11 \text { videocassettes or fitms, Instruc- } \\
\text { tor's Guide ( } 8 \text { pgs.) }\end{array}$ & $\begin{array}{l}153 \text { instructional activity cards, Teacher's } \\
\text { Guide ( } 3 \text { pgs.), Objective Profile Sheets, } \\
\text { and storage box. }\end{array}$ & $\begin{array}{l}\text { Four softbound story/workbooks. } \\
\text { A Teacher's Guide ( } 4 \text { pgs.) with answer } \\
\text { key accompanies each workbook. }\end{array}$ & $\begin{array}{l}\text { A four-part program including } 4 \text { film- } \\
\text { strips, } 4 \text { audiocassettes, student work- } \\
\text { books, } 4 \text { Instructor's Guides ( } 2 \text { pgs. } \\
\text { each), and consequence cards. }\end{array}$ \\
\hline $\begin{array}{l}\text { Ability and/or } \\
\text { Motivational } \\
\text { Components }\end{array}$ & $\begin{array}{l}\text { Ability by observing good and poor } \\
\text { models of skill use in a TV game } \\
\text { show format and by practicing the } \\
\text { behavior. Motivation by reinforce- } \\
\text { ment of appropriate social behavior. }\end{array}$ & $\begin{array}{l}\text { Ability by allowing instructors to } \\
\text { set realistic instructional goals and } \\
\text { by providing activities for accom- } \\
\text { plishing these goals. }\end{array}$ & $\begin{array}{l}\text { Motivation by having learners con- } \\
\text { sider the characters' actions in } \\
\text { light of the consequences of those } \\
\text { actions. Learners suggest socially } \\
\text { skilled ways for the characters to } \\
\text { deal with their problems. }\end{array}$ & $\begin{array}{l}\text { Motivation by having learners con- } \\
\text { sider the consequences of their } \\
\text { actions. }\end{array}$ \\
\hline $\begin{array}{l}\text { Learning } \\
\text { Characteristics } \\
\text { Addressed }\end{array}$ & $\begin{array}{l}\text { The programs are simple, easy to } \\
\text { understand, and require no reading } \\
\text { or writing. Pleasant, capable models } \\
\text { who possess characteristics } \\
\text { similar to the learners are shown. } \\
\text { Very basic problem-solving tech- } \\
\text { niques are given. Acceptable social } \\
\text { behavior is reinforced with posters, } \\
\text { applause and "thumbs-up" } \\
\text { gestures. }\end{array}$ & $\begin{array}{l}\text { The cards are designed for the in- } \\
\text { structor to use to write IEPs and to } \\
\text { teach skills. Many of the activities } \\
\text { recommended require reading and } \\
\text { writing at a level determined by the } \\
\text { teacher. Reinforcement is men- } \\
\text { tioned briefly in the Teacher's } \\
\text { Guide. The wide variety of activities } \\
\text { recommended aids generalization. }\end{array}$ & $\begin{array}{l}\text { The reading level is low. (Reading } \\
\text { level=2.5, Spache). Writing require- } \\
\text { ments include one-sentence an- } \\
\text { swers. The plays are simple and } \\
\text { easy to understand. The concepts } \\
\text { and story lengths progress from } \\
\text { easy to hard. Resolution of conflict } \\
\text { through simplified problem-solving } \\
\text { techniques is included in each } \\
\text { book. An answer key is given. }\end{array}$ & $\begin{array}{l}\text { The program is simple and easy to } \\
\text { understand. (Reading level=3.0, } \\
\text { method not specified.) Concepts and } \\
\text { terminology are explained in the } \\
\text { overview, which acts as an advance } \\
\text { organizer. Activities progress from an } \\
\text { easy-to-hard sequence. Problem } \\
\text { solving is taught by having the stu- } \\
\text { dent: } \\
\text { a. identify the problem } \\
\text { b. generate alternatives } \\
\text { c. identify consequences. }\end{array}$ \\
\hline $\begin{array}{l}\text { Skills or Topics } \\
\text { Covered }\end{array}$ & $\begin{array}{l}\text { Keeping Busy } \\
\text { Looking Good } \\
\text { Clothes That Fit } \\
\text { Neat in the Street } \\
\text { Lost } \\
\text { Keep Your Cool } \\
\text { Private Property } \\
\text { Strangers } \\
\text { Table Manners } \\
\text { Friendly Hello }\end{array}$ & $\begin{array}{l}\text { Physical Health } \\
\text { Mental Health } \\
\text { First Aid } \\
\text { Cleanliness and Grooming } \\
\text { Clothing } \\
\text { Foods and Nutrition } \\
\text { Home Maintenance } \\
\text { Basic Etiquette } \\
\text { Interpersonal Relationships } \\
\text { Communication } \\
\text { Family Living } \\
\text { Leisure Activities } \\
\text { Occupational Orientation } \\
\text { Job Seeking } \\
\text { Job Application } \\
\text { Job Maintenance } \\
\text { Consumer Information } \\
\text { Community Participation }\end{array}$ & $\begin{array}{l}\text { dealing with conflict } \\
\text { dealing with authority } \\
\text { responsibility } \\
\text { decision making } \\
\text { problem solving }\end{array}$ & $\begin{array}{l}\text { Overview } \\
\text { Social Consequences at Work } \\
\text { dependability } \\
\text { interpersonal relations } \\
\text { customer relations } \\
\text { Social Consequences at Home } \\
\text { family problems } \\
\text { home conflicts } \\
\text { Social Consequences at School } \\
\text { responsibility } \\
\text { authority } \\
\text { peer group pressure }\end{array}$ \\
\hline $\begin{array}{l}\text { Approach (Skills or } \\
\text { Situations) }\end{array}$ & $\begin{array}{l}\text { General skills approach: Each topic } \\
\text { is introduced and followed by } \\
\text { examples of good and poor be- } \\
\text { havior in several situations. Learners } \\
\text { rate the models' skill pertormances. }\end{array}$ & $\begin{array}{l}\text { General skills approach: Skills are } \\
\text { developed through a variety of } \\
\text { activities specified for each ob- } \\
\text { jective. Situations in which the } \\
\text { skills are used are discussed within } \\
\text { the learning setting. }\end{array}$ & $\begin{array}{l}\text { Problem-specific approach: The } \\
\text { books address situations in which } \\
\text { one or more characters in each } \\
\text { play is lacking in social skills. } \\
\text { Written activities address what hap- } \\
\text { pened, consequences of actions, } \\
\text { and how each situation could have } \\
\text { been resolved more skillfully. }\end{array}$ & $\begin{array}{l}\text { Problem-specific approach: Emphasis } \\
\text { is on the situations in which adolescents } \\
\text { find themselves, possible responses } \\
\text { to those situations, and the con- } \\
\text { sequences resulting from those } \\
\text { responses. }\end{array}$ \\
\hline $\begin{array}{l}\text { Teaching } \\
\text { Methodology }\end{array}$ & $\begin{array}{l}\text { Awareness by viewing the program } \\
\text { and participating in group dis- } \\
\text { cussion. } \\
\text { Practice by role playing in the } \\
\text { game show format. Guidelines are } \\
\text { given in the Instructor's Guide, but } \\
\text { specific situations for practice are } \\
\text { not given. } \\
\text { Application by reinforcement of } \\
\text { proper behavior during non-viewing } \\
\text { periods is suggested. Also, self- } \\
\text { monitoring of behavior by the lear- } \\
\text { ners is recommended. } \\
\text { Models } \\
\text { Reinforcement } \\
\text { Repetition }\end{array}$ & $\begin{array}{l}\text { Awareness by participating in class } \\
\text { discussions, listening to guest lec- } \\
\text { turers, going on field trips, etc. } \\
\text { Practice by role playing in a few } \\
\text { activities. } \\
\text { Guidelines are given for structuring } \\
\text { the practice, but no specific sit- } \\
\text { uations are provided. } \\
\text { Reinforcement } \\
\text { Mastery Criteria for fulfilling objec- } \\
\text { tives } \\
\text { Models }\end{array}$ & $\begin{array}{l}\text { Awareness by reading the plays } \\
\text { and completing the written activi- } \\
\text { ties. } \\
\text { Practice by role playing alternative } \\
\text { behaviors is suggested in the Tea- } \\
\text { cher's Manual, but no guidelines or } \\
\text { situations are given. }\end{array}$ & $\begin{array}{l}\text { Awareness by viewing the filmstrips } \\
\text { and completing the workbook acti- } \\
\text { vities. } \\
\text { Practice by role playing is suggested } \\
\text { in the Instructor's Guide, but no } \\
\text { specific guidelines are given. } \\
\text { Application by a log of outside exper- } \\
\text { iences is suggested in the Instructor's } \\
\text { Guide, but no specific guidelines are } \\
\text { given. }\end{array}$ \\
\hline
\end{tabular}


workbooks. The curriculum also includes situations that can be used to extend the games depicted in the filmstrips to the classroom. The games are designed to give students an opportunity to try out and refine their social judgment and skills.

Two additional teacher's guides are included. The first, a Media Teacher's Guide, presents strategies for using the filmstrips to motivate students and reinforce learning. The second, Teacher's Orientation, gives a detailed description of attribution theory-the psychological theory upon which Marathon is based. It also includes a trainer's guide for inservice workshops.

How does the Marathon program promote social competence? The purpose of the Marathon program is to help students develop adaptive motivation systems, social skills, and behaviors that will bring them success. The program is based on attribution theory, which suggests that individuals feel more motivated if they have a sense of control over their own lives. Consequently, Marathon makes a systematic attempt to help students develop a greater sense of control by emphasizing effort and encouraging students to see their own efforts as the primary cause of their successes. Conversely, students are encouraged to view a lack of effort as the primary cause of failure.

Attribution theory is integrated with a variety of skills into the Marathon program through short stories and examples. Example skills included in the stories are the skills for job interviewing, making friends, problem solving, following instructions, getting help, and accepting criticism.

How does Marathon accommodate specific learner characteristics? The Marathon curriculum is designed to accommodate a number of learner characteristics, including poor reading and writing skills. The materials are written at a third grade reading level, with minimum writing required. Students are often given the option to draw rather than write the answer. New vocabulary words are listed in the teacher's guide to each lesson. The material avoids unnecessary detail so that the students will not be distracted. It also employs easy-to-read lettering, twocolumn typesetting, and sufficient white space to promote easy use of the materials. Specific descriptions of problem solving are included.

Do the skills on which Marathon focuses correspond to identified deficits? The Marathon curriculum is directed at two broad classes of skills-those necessary for getting along with others, and job related skills. A literature review, the developer's experience, and a survey of teachers were used to identify areas of skill deficiencies. These skill deficiencies are emphasized in the workbooks and game exercises.
Does the Marathon program focus on both the skills and the situations in which the skills can be used? The Marathon materials relate the skills taught to specific situations by using illustrative stories. In the student workbooks, different skills are depicted through stories about adolescents at job settings and with friends. These stories illustrate a variety of common problem situations encountered by teenagers, and ways to solve the various problems by utilizing the skills.

What teaching methodology does the Marathon program employ? The Marathon materials incorporate both workbooks and audiovisual materials to provide an awareness of the concepts. This is accomplished by having the student read and answer questions or puzzles concerning the content or watch filmstrips illustrating the skills. In addition, situation cards have been developed for practicing the skills in simulated situations. Further, group discussions and games are used to promote awareness and practice of various skills. The teacher's guides suggest homework assignments to promote application of the skills to real life settings.

\section{The Social Solutions Curriculum}

The Social Solutions curriculum, developed by the American Institute for Research (AIR), incorporates instructional, assessment, and resource components. It is intended for use by trainers, counselors, enablers, teachers, and psychologists working as "mentors" in either academic or community-based settings. The materials are appropriate for young adults who are mildly mentally retarded, learning disabled, or emotionally disturbed.

A diagnostic-prescriptive approach to individualizing skill development activities underlies the organization of the Social Solutions Curriculum. Whether learners are in classroom settings or working individually with counselors, profiles of their social skill strengths and weaknesses are developed in as many as 11 domains. The package is designed to organize and facilitate the functions of a mentor, who guides the learners through profiling, skill development, and progress assessment activities in areas of relative weakness.

The curriculum has several main components. For the mentor, the central component is the Mentor's Manual.It gives background in social learning theory, a description of the entire curriculum package and how it is to be used, guidance in how to individualize instruction and carry out group sessions, and information about available assessment strategies, instructional strategies, and resources outside of the Social Solutions materials.

For the learner, the central component is an individualized Personal Growth Plan. This plan is a set of 
profiling, planning, and reporting forms on which learners can indicate their present status in one or more social skill areas and what they would like to accomplish. This system permits reporting of progress in a manner that leads directly to updating of learner profiles and reflects small increments of growth, thereby reinforcing and motivating learners.

For group instruction activities, the mentors have 14 detailed Group Study Units available for use. Eleven of these cover the social skills areas or domains. Two other units are intended to facilitate the mentor's introduction of the curriculum to learners in a classrooom setting. The last Group Study Unit is a summary of class outcomes. For individual or group instruction activities, the learners have a set of 170 cards, called Learning Activity Cards, each containing instructions for developing specific personalsocial skills.

The final component of the Social Solutions package is a set of media, including a videocassette and three audiocassettes. The videocassette presents vignettes of individuals in community, school, and work settings who are facing problems in social situations in which effective skills are either clearly present or absent. One of the audiocassettes explains relaxation techniques, a second presents a number of brief role play exercises, and the third is designed to orient mentors to the Social Solutions curriculum.

How does the Social Solutions curriculum promote social competence? The Social Solutions curriculum promotes social competence by focusing primarily on the abilities necessary to act appropriately. Eleven social skill areas (e.g., handling stress and conflict, taking responsibility for actions and decisions, communicating effectively, and contributing to groups) have been targeted for training. Each area contains a number of specific skills (e.g., handling rejection, ignoring teasing, and negotiating solutions). Eighty-five specific skills, called "learning points," are identified across the 11 areas, with more learning points in the higher priority areas.

How does the Social Solutions curriculum respond to specific learner characteristics? The staff of AIR began with an initial determination of the characteristics of the three target populations. They identified characteristics for the learning disabled, including that they are easily frustrated, withdrawn, unlikely to ask for help, anxious, and poor at transferring learning. The major characteristics of the mentally retarded that were addressed include problems of generalizability and discrimination, poor reading abilities, and the need for problems to be broken into small steps. For the emotionally disturbed, project personnel determined that materials should be developed with tact, individualized, written at an appropriate reading level, and interesting and flexible. All these factors were integrated during development of the materials.

Individual activity cards for the learners are written at two different reading levels (about fourth and sixth grade difficulty). In addition, the information is presented in a variety of formats (e.g., videotape, audiotape, group instruction, and self-study).

Do the skills on which the Social Solutions curriculum focuses correspond to learner deficits? To determine the instructional content of the materials, the AIR staff conducted a literature search and also interviewed 24 service providers who worked with the three target populations across the country. This resulted in the identification of 25 target areas, which were reduced to a list of 11 core areas. The list was prioritized through the use of additional interviews with the practitioners, in which they were asked to rank the 11 areas in importance to their clients. After the core areas were prioritized, skills were developed within each area, emphasizing the more highly prioritized areas. The resulting list of skills covers the common areas of skill deficiency of the mildly handicapped young adult.

Does the Social Solutions curriculum focus on both the skills and the situations in which the skills can be used? The Social Solutions curriculum ties the target skills to specific situations in the Learning Activity Cards. In these cards, skills are illustrated through short stories that provide a specific situation example in which the skill could be used, followed by a description of and rationales for using the skill. In addition, the learner must meet specific mastery criteria that include personal application of the skill to a situation in his/her life.

What teaching methodology does the Social Solutions curriculum employ? The teaching methodology employed in the Social Solutions curriculum includes awareness, practice, and application procedures. An awareness of the skills is promoted through the Learning Activity Cards, the Group Instruction activities, and media materials. These materials provide an introduction to the skills and situations in which the skills can be used. The same materials also provide practice in the skills. For example, the Group Instruction activities provide opportunities for role playing the skills in simulated settings. The Learning Activity Cards include application activities, which require the students to perform the skill in naturally occurring situations.

\section{The Social Skills Curriculum}

The Social Skills Curriculum, developed by the University of Kansas Institute for Research in Learning Disabilities, was designed to address the social skill needs 
of mildly handicapped adolescents and young adults by teaching them the social skills necessary for successful interaction in education, occupational, and community settings. The curriculum includes an Instructor's Manual, which describes the various activities, ways to assess entry into the curriculum, management procedures, and the instructor's role in each type of activity.

The major instructional component of the curriculum is a set of 30 skill workbooks. Each workbook contains awareness, practice, and application material for one of the targeted social skills. Accompanying the workbooks are 13 comic books, each of which illustrates use of a cluster of related social skills through science fiction adventure stories.

In addition, the curriculum contains answer booklets for the learners to record their responses to the questions in the workbooks, rating scales for learners and instructors to use in determining initial placement of the learners within the curriculum, and various management tools to help the instructor organize and monitor learner use of the materials.

How does the Social Skills Curriculum promote social competence? The Social Skills Curriculum is based on the idea that a social skill is complex, and competence in performing the skill in the real world is based on several subskills. For example, an individual must be aware of what a social skill is, the kinds of situations in which it is appropriately used, the consequences for using the skill, and the nonverbal and verbal components of the skill before he or she can begin to use the skill. Additionally, the individual must be able to discriminate situations in which the skill is appropriate, be knowledgeable of rules or social mores that govern use of the skill, and be motivated to perform the skill.

Thus, the Social Skills Curriculum promotes social competence by teaching learners to actually perform synchronized components of social skills in real life situations, as well as by motivating them to perform the skills. Motivation is facilitated through use of rationales (explanations of consequences that are likely to occur/ not occur following social skill usage/non-usage) and illustrations of consequences in the comic books.

How does the Social Skills Curriculum respond to specific learner characteristics? The Social Skills Curriculum is targeted for three groups of mildly handicapped adolescents and young adults ranging in age from 12 to 21 years: the learning disabled, the mildly mentally retarded, and the emotionally disturbed. The curriculum may also be used with nonhandicapped adolescents who are lacking in social skills.

The Social Skills Curriculum was designed to respond to the unique learning characteristics of the three mildly handicapped populations. A number of learner characteristics common to the three target populations have been identified. These characteristics were translated into the following design features that were incorporated into the Social Skills curriculum:

1. The material is written at a low readability level (fourth to fifth grade reading level), and each unit is accompanied by a glossary of difficult terms.

2. Advance organizers are included to provide a conceptual framework for the learner.

3. Cuing is used to help learners understand and remember the material.

4. Problem solving skills are included in the curriculum.

5. The amount of required writing is minimized through multiple choice and fill-in-the-blank formats.

6. The skill steps and rules necessary to perform the skills are taught.

7. Learners are taught to discriminate situations in which social skills can be performed.

8. Memorization of the skill steps is programmed such that learners are provided with and required to use a strategy for remembering items in a list.

9. The curriculum includes specific procedures to aid generalization.

10. The curriculum includes rationales to increase the learner's motivation to use the skills.

11. The material can be practically used in programs for the mildly handicapped including resource rooms, self-contained classrooms, regular classrooms, community colleges, or group homes.

12. The materials are age-appropriate for adolescents and young adults.

13. The materials are programmed to promote the learner's success, to reduce the possibility of failure both during learning and application of the skills.

14. A sequence of skills from easy to hard is recommended in the Instructor's Manual.

15. The curriculum focuses on skills applicable to educational, occupational, and community living settings, to increase a person's ability to live independently.

Do the skills on which the Social Skills Curriculum focuses correspond to identified deficits? Skills taught through the Social Skills Curriculum were identified through a literature review process and through a survey of mildly handicapped persons, teachers, and parents of mildly handicapped persons and validated by teachers of 
the mildly handicapped, experts in the field of the mildly handicapped, and experts in the field of social skills.

Thirty social skills were identified. Example skills are making friends, asking for help, negotiating, resisting peer pressure, joining group activities, accepting criticism, and responding to teasing. These include all the skills commonly identified in the research literature as needed by mildly handicapped adolescents and young adults.

Does the Social Skills Curriculum focus on both skills and situations in which the skills can be used? Part of the mastery requirement for each general skill is demonstrated competence in a group of practice situations that have been specified for each skill. These situations correspond to two developmental levels and are grouped into three environmental realms (educational, employment, and community). For example, a student learning to accept criticism in the occupational realm at the lower developmental level might practice accepting criticism from his/her neighbor for not cutting the grass properly. A student learning to apply the accepting criticism skill at the upper level might practice accepting criticism from his/her boss for not completing an inventory report on time.

These practice situations were identified for the curriculum through interviews with parents, teachers, and mildly handicapped adolescents and young adults. Twenty different practice situations were identified for each skill. The student must demonstrate mastery by performing the skill perfectly in each of the three environmental realms.

What teaching methodology does the Social Skills Curriculum employ? Awareness, practice, and application activities are programmed for the learners in the 30 workbooks. The comic books also promote awareness of the skills. The awareness section of each workbook has written text, illustrative pictures, multiple choice questions, and a programmed instructional section designed to facilitate memorization of the skill steps for a particular skill.

The next part of each workbook, the practice section, contains a self-modeling script, role play instructions and situations, and a checklist for assessing the learner's performance in role play situations. The learners are required to practice the skills in simulated, age-appropriate, role playing situations with another learner (or the teacher) acting as practice partner and "helper." The helper evaluates the learner's performance using the checklist and provides feedback to the learner. Exercises included in the Instructor's Manual are designed to teach students, through role play activities, to discriminate when to use the social skills that have been previously learned.

Application activities are represented through the "Missions Game," designed to promote generalization of the skills. In the game, learners carry out missions by surprising each other with situations that require use of the skill during naturally occurring interactions. Teachers also participate in the game by presenting opportunities for skill use within the natural milieu. Checklists are used to assess the learner's performance of the skill steps at this application level. As learners become proficient in using the skill in the learning environment, the game is extended to settings outside the learning environment. Students set goals to use the skills elsewhere and report to the teacher about their performance of the skills.

\section{SUMMARY}

A common characteristic of mildly handicapped adolescents is their inability to respond appropriately in social situations. Their social skill deficits may limit their opportunities in educational, occupational, and community realms. Few instructional resources are available commercially for teaching social skills to mildly handicapped adolescents: Too often, the lack of available materials has resulted in this important element of their educational program being slighted.

This article discusses five factors that should be considered when selecting a social skill curriculum for use with the mildly handicapped. Some of the currently available curricula meet a number of these criteria, but few of the currently available programs were designed specifically for use with the mildly handicapped adolescent.

In 1981, the U.S. Department of Education, in response to the lack of social skills programs designed for the mildly handicapped, funded three separate curriculum development projects that have produced the Marathon program, the Social Solutions curriculum, and the Social Skills Curriculum. Each of these projects has developed and extensively field-tested a unique social skills curriculum designed specifically for the mildly handicapped adolescent and/or young adult. Each curriculum is described and discussed according to the five criteria for evaluating a social skill curriculum. The purpose of this review is to help teachers evaluate and choose the most appropriate social skills curriculum for their needs. All of the recently developed social skills curricula are or should be available commercially in the near future. ${ }^{1}$

\footnotetext{
Information regarding the distribution of the three recently developed social skills curricula is available from the following organizations:

Marathon, Stanfield Film Assoc., P.O. Box 1983, Santa Monica, CA 90406

Social Solutions, Professional Associated Resources, 2917 Adeline Dr., Burlingame, CA 94010

Social Skills Curriculum, Institute for Research in Learning Disabilities, 313 Carruth O'Leary Hall, Lawrence, KS 66045.
} 


\section{ADDRESSES OF PUBLISHERS OF CURRENTLY AVAILABLE SOCIAL SKILLS CURRICULA}

American Guidance Service
Publishers' Building

Bennett Publishing Co.

Peoria, IL 61615

Developmental Learning Materials

P.O. Box 4000

One DLM Park

Allen, TX 75002

Ebsco Curriculum Materials

Box 11542

Birmingham, AL 35202

Hubbard

P.O. Box 104

Northbrook, IL 60062

Human Relations Media

175 Tompkins Ave.

Pleasantville, NY 10570
Circle Pines, MN 55014

\author{
Interpretive Education \\ Communications Park \\ Box 3000 \\ Mt. Kisco, NY 10549
}

Janus Book Publishers

Department E24

250I Industrial Pky.

Hayward, CA 94545

Media Materials, Inc.

2936 Remington Ave.

Baltimore, MD 21211

Research Press

Box 31773

Champaign, IL 61821

The Ungame Co.

P.O. Box 6382

Anaheim, CA 92806

\section{REFERENCES}

Alley, G.R., \& Deshler, D.D. Teaching the learning disabled adolescent: Strategies and methods. Denver: Love Publishing Co., 1979.

Arnold, S., Sturgis, E., \& Forehand, R. Training a parent to teach communication skills. Behavior Modification, 1977, 1, 259-276.

Butterfield, E.C., \& Belmont, J.M. Assessing and improving the executive cognitive function of mentally retarded people. In 1 . Bialer \& M. Sternlicht (Eds.), The psychology of mental retardation. New York: Psychological Dimensions, 1977.

Clark, H.B., Caldwell, C.P., \& Christian, W.P. Classroom training of conversational skills and remote programming for the practice of these skills in another setting. Child Behavior Therapy, 1979, 1, 139-160.

Cohn, Y. Criteria for the probation officer's recommendation to the juvenile court. Crime \& Delinquency, 1963, 9, 262-275.

Combs, M.L., \& Slaby, D.A. Social skills training with children. In B.B. Lahey \& A.E. Kazdin (Eds.), Advances in clinical child psychology (Vol. 1). New York: Plenum Press, 1977.

Dale, E., \& Chall, J. A formula for predicting readability. Educational Research Bulletin, 1948, 27, 11-20, 37-54.

Deshler, D.D., Schumaker, J.B., Warner, M.M., Alley, G.R., \& Clark, F.L. An epidemiological study of learning disabled adolescents in secondary schools: Social status, peer relationships, activities in and out of school, and time use (Research Report No. 18). Lawrence, KS: University of Kansas Institute for Research in Learning Disabilities, 1980.

Foster, S.L., \& Ritchey, W.L. Issues in the assessment of social competence in children. Journal of Applied Behavior Analysis, 1979, $12,625-638$.

Fulton, R.W. Job retention of the mentally retarded. Mental Retardation, 1975, 13, 26-27.

Goldfried, M.R., \& D'Zurilla, T.J. A behavioral-analytic model for assessing competence. In C.D. Spielberger (Ed.), Current topics in clinical and community psychology. New York: Academic Press,
1969.

Gorney-Krupshaw, B., Atwater, J., Powell, L., \& Morris, E.K. Improving social interactions between learning disabled adolescents and teachers: $A$ child effects approach (Research Report No. 45). Lawrence, KS: University of Kansas Institute for Research in Learning Disabilities, 1981.

Gozali, J. Perception of the EMR special class by former students. Mental Retardation, 1972, 10, 34-35.

Gresham, F.M. Social skills training with handicapped children: A review. Review of educational research, 1981, 51, 139-176.

Gross, S.Z. The prehearing juvenile report: Probation officer's conception. Journal of Research in Crime \& Delinquency, 1967, 4, 212-217.

Grossman, H.J. (Ed.). Manual on terminology and classification in mental retardation (rev.) Washington, DC: American Association on Mental Deficiency, 1973.

Hallahan, D.P., \& Kauffman, J.M. Labels, categories, and behaviors: ED, LD, and EMR reconsidered. Journal of Special Education, 1977, 11, 139-149.

Hallahan, D.P., \& Kauffman, J.M. Exceptional children: Introduction to special education. Englewood Cliffs, NJ: Prentice-Hall, 1978.

Hazel, J.S., Schumaker, J.B., Sherman, J.A., \& Sheldon, J. Application of a group training program in social skills and problem solving skills to learning disabled and non-learning disabled youth. Learning Disability Quarterly, 1982, 5, 398-408.

Hazel, J.S., Schumaker, J.B., Sherman, J.A., \& Sheldon-Wildgen, J. The development and evaluation of a group skills training program for court-adjudicated youths. In D. Upper \& S. Ross (Eds.), Behavioral Group Therapy, 1981, pp. 113-152.

Heal, F.W., \& Johnson, J.T., Jr. Inhibition deficits in retardate learning and attention. In N.R. Ellis (Ed.), International review of research in mental retardation (Vol. 4). New York: Academic Press, 1970.

Hewett, F.M. Education of exceptional learners. Boston: Allyn \& Bacon, 1977.

Kauffman, J.M. Characteristics of children's behavior disorders. Columbus, OH: Charles E. Merrill, 1977.

Kelly, J.A., \& Drabman, R.S. The modification of socially detrimental behavior. Journal of Behavior Therapy \& Experimental Psychiatry, 1977, 8, 101-104.

Kelly, J.A., Furman, W., Phillips, J., Hathorn, S., \& Wilson, T. Teaching conversational skills to retarded adolescents. Child Behavior Therapy, 1979, 1, 85-97.

Kelly, J.A., Wildman, B.G., Urey, J.R., \& Thurman, C. Group skills training to increase the conversational repertoire of retarded adolescents. Child Behavior Therapy, 1979, 1, 323-336.

Libet, J.M., \& Lewinsohn, P.M. Concept of social skills with special reference to the behavior of depressed persons. Journal of Consulting \& Clinical Psychology, 1973, 40, 304-312.

MacMillan, D.L. Mental retardation in school and society. Boston: Little, Brown, 1977.

Mathews, R.M., Whang, P.L., \& Fawcett, S.B. Behavioral assessment of occupational skills of learning disabled adolescents (Research Report No. 5). Lawrence, KS: University of Kansas Institute for Research in Learning Disabilities, 1980.

Mellard, D.M., \& Alley, G.R. Production deficiency vs. processing dysfunction: Experimental assessment of $L D$ adolescents (Research Report No. 40). Lawrence, KS: University of Kansas Institute for Research in Learning Disabilities, 1981.

Rinn, R.C., \& Markle, A. A modification of social skill deficits in children. In A.S. Bellack \& M. Hersen (Eds.), Research and practice in social skills training. New York: Plenum Press, 1979.

Robinson, M.M., \& Robinson, H.B. The mentally retarded child. New York: McGraw-Hill, 1976.

Rychtarik, R.G., \& Bornstein, P.H. Training conversational skills in mentally retarded adults: A multiple baseline analysis. Mental Retardation, 1979, 17, 289-293.

Schumaker, J.B., \& Ellis, E. Social skills training of LD adolescents: A generalization study. Learning Disability Quarterly, 1982, 5, 409-414.

Schumaker, J.B., Hazel, J.S., Sherman, J.A., \& Sheldon, J. Social skill performances of learning disabled, non-learning disabled, and 


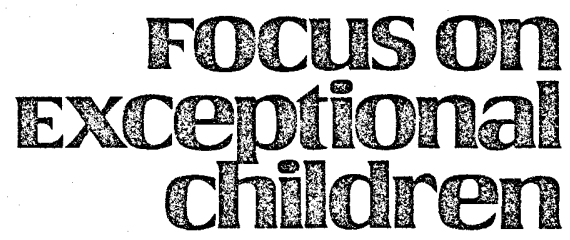

delinquent adolescents. Learning Disability Quarterly, 1982, 5, 388-392.

Seabaugh, G.O., \& Schumaker, J.B. The effects of self-regulation training on the academic productivity training of $L D$ and $N L D$ adolescents (Research Report No. 37). Lawrence, KS: University of Kansas Institute for Research in Learning Disabilities, 1981.

Siegel, E. The exceptional child grows up. New York: Dutton, 1974.

Tollefson, N., Tracy, D.B., Johnsen, E.P., Borgers, S., Buenning, M., Farmer, A., \& Barke, C.R. An application of attribution theory to developing self-esteem in learning disabled adolescents (Research Report No. 23). Lawrence, KS: University of Kansas Institute for Research in Learning Disabilities, 1980.

Vale, C.A. National needs assessment of educational media and materials for the handicapped. Berkeley, CA: Educational Testing Service, 1978.

Vetter, A. A comparison of the characteristics of learning disabled and non-learning disabled young adults. Unpublished doctoral dissertation, University of Kansas, 1983.

Warner, M.M., Alley, G.R., Schumaker, J.B., Deshler, D.D., \& Clark, F.L. An epidemiological study of learning disabled adolescents in secondary schools: Achievement and ability, socioeconomic status, and school experience (Research Report No. 13). Lawrence, KS: University of Kansas Institute for Research in Learning Disabilities, 1980.
Warner, M.M., Schumaker, J.B., Alley, G.R., \& Deshler, D.D. The performance of learning disabled, low-achieving, and normalachieving adolescents on a serial recall task: The role of executive control (Research Report No. 55). Lawrence, KS: University of Kansas Institute for Research in Learning Disabilities, 1983.

Whang, P.L., Fawcett, S.F., \& Mathews, R.M. Teaching job-related social skills to learning disabled adolescents (Research Report No. 42). Lawrence, KS: University of Kansas Institute for Research in Learning Disabilities, 1981.

White, W.J., Schumaker, J.B., Warner, M.M., Alley, G.R., \& Deshler, D.D. The current status of young adults identified as learning disabled during their school career (Research Report No. 21). Lawrence, KS: University of Kansas Institute for Research in Learning Disabilities, 1980.

Zeaman, D., \& House, B.J. The role of attention in retardate discrimination learning. In N.R. Ellis (Ed.), Handbook of mental deficiency. New York: McGraw-Hill, 1963.

Zigmond, N. A prototype of comprehensive services for secondary students with learning disabilities. Learning Disability Quarterly, 1978, 1, 39-49.

Zigmond, N., \& Brownlee, J. Social skills training for adolescents with learning disabilities. Exceptional Education Quarterly, 1980, 1, 77-83.

\section{professional update}

\section{NEW BOOK}

\section{School Violence \\ Arnold P. Goldstein, Steven J. Apter, and \\ Berj Harootunian}

Yet another book addresses the pervasive problem of violence in the schools. This one presents potential solutions as arising from prosocial values and behaviors. First, the authors relate the economic and social costs of the problem, and its effects on teachers, student victims, school property, the community, and the educational process in general. Separate chapters discuss the teacher as decision maker, behavior-modification techniques, psychodynamic and humanistic interventions, teaching prosocial values, teaching prosocial behaviors, the role of the school, and community intervention.

The basic position of this book is that the failure to reduce aggression in America's schools is largely a failure of perspective; the controls exist, but they have been utilized in an unsystematic, unidimensional manner. Corrective steps must focus on, in addition to the student involved, the teacher and colleagues, the school and its curricula and organization, and the community and state in which the school is located-as a whole. A systems approach to aggression controls, alternatives, and prevention is the heart of the book.

Prentice-Hall, Englewood Cliffs, NJ 07632 is the publisher of this 250-page hardcover book. The authors are available to conduct workshops; for further information contact: Dr. Arnold P. Goldstein, School Violence Consultants, 129 Nottingham Rd., Syracuse, NY 13210.

$$
* * *
$$

The 37th Biennial Convention of the National Association of the Deaf will take place July 3-8, 1984, in Baltimore. It is hosted by the Maryland Association of the Deaf. For information about exhibits, tickets, hotel reservations, or the program, contact William E. Stevens, 10317 Royal Rd., Silver Spring, MD 20903. For workshop and seminar information, write Roslyn Rosen, Dean, College of Continuing Education, Gallaudet College, Washington, DC 20002. 